\title{
Relacións hídricas, nutrición e transporte nas plantas
}

\author{
Ma Carmen Rodríguez Gacio \\ Área Fisioloxía Vexetal \\ Departamento Fisioloxía Vexetal \\ Escola Politécnica Superior
}

\section{unidadesdiddácticas}


(C) Universidade de Santiago de Compostela, 2015

\section{Deseño e maquetación}

J. M. Gairí

\section{Edita}

Servizo de Publicacións e Intercambio Científico da Universidade de Santiago de Compostela usc.es/publicacions

ISBN

978-84-16533-35-0

$\mathrm{DOI}$

http://dx.doi.org/10.15304/9788416533350 
MATERIA: Fisioloxía Vexetal

TITULACIÓN: Enxeñaría Técnica en Informática de Sistemas

PROGRAMA XERAL DO CURSO

Localización da presente unidade didáctica

Unidade I. Relacións hídricas, nutrición e transporte nas plantas

Osmose e potencial hídrico

Absorción da auga e transporte polo xilema

Transporte a través do floema: carga e descarga

O solo e a planta

Absorción de nutrientes pola raíz

Interacións con microorganismos na rizosfera

Unidadell. Control do rendemento biolóxico e económico das plantas

Unidade III. Fisioloxía do desenvolvemento: control endóxeno e exógeno

Unidade IV. Fisioloxía en condicións de estrés

Unidade V. Introdución á biotecnoloxía vexetal 
ÍNDICE

\section{PRESENTACIÓN}

Xustificación da unidade temática no contexto da materia e da titulación

Duración e destinatarios

\section{OBXECTIVOS}

\section{METODOLOXÍA}

\section{CONTIDOS}

1. Propiedades físicas e químicas da auga

2. Osmose e potencial hídrico

\subsection{Osmose}

2.2. Potencial hídrico

3. Absorción da auga e transporte polo xilema

3.1. Absorción da auga: ruta simplástica e apoplástica

3.2. Transporte da auga polo xilema

4. Transporte a través do floema: carga e descarga

5. O solo e a planta

5.1. Deficiencia de nutrientes

5.2. Dispoñibilidade de nutrientes no solo

5.3. Solos salinos e ácidos

\subsubsection{Solos salinos}

\subsubsection{Solos ácidos}

6. Absorción de nutrientes pola raíz

6.1. Factores que afectan á absorción radical

7. Interaccións con microorganismos na rizosfera

7.1. Nódulos

7.2. Micorrizas

7.3. Comparación entre micorrizas e nódulos

\section{ACTIVIDADES PROPOSTAS}

\section{AVALIACIÓN}

\section{BIBLIOGRAFÍA}

Recursos en internet 


\section{PRESENTACIÓN}

Esta unidade didáctica denominada «Relacións hídricas, nutrición e transporte nas plantas» forma parte da materia «Fisioloxía vexetal» que se imparte no primeiro semestre do 2ㅇ curso do Grao en «Enxeñaría Agrícola e Agroalimentaria». Esta materia trata dos distintos procesos fisiolóxicos que acontecen nas plantas. Nunha primeira parte, estúdase como a importancia da auga para os seres vivos é consecuencia das súas propiedades físicas e químicas exclusivas. Por outra parte, analízase o transporte da auga e os nutrientes na planta. A continuación, trátase dos factores endóxenos e exóxenos que regulan a fotosíntese. Posteriormente, trátase de coñecer a regulación endóxena e exóxena do desenvolvemento das plantas e como é a fisioloxía da planta en condicións de estrés. Por último, analízanse as técnicas e aplicacións utilizadas na biotecnoloxía vexetal. Polo tanto, a materia estrutúrase en diferentes unidades didácticas que corresponde a diferentes temas como se amosa no seguinte esquema.
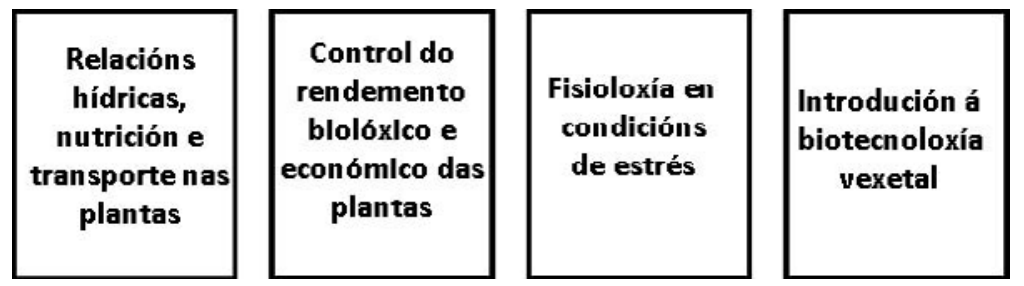

Na Unidade Didáctica "Relacións hídricas, nutrición e transporte nas plantas» preténdese amosar as bases do proceso de absorción, nutrición e transporte nas plantas.

\section{Xustificación da unidade temática no contexto da materia e da titulación}

A Fisioloxía Vexetal é a ciencia que estuda o funcionamento das plantas. Esta disciplina ten gran repercusión na Agronomía e polo tanto nas actividades do Enxeñeiro Agrícola. Así, por exemplo, o aumento da produtividade das explotacións agrícolas é consecuencia directa dos coñecementos en Fisioloxía Vexetal que permitirán optimizar aspectos tan diversos como a subministración de auga e de nutrientes, a distribución de fotoasimilados nas plantas favorecendo aquelas partes utilizables ou a mellora da calidade.

Unha das competencias específicas da formación básica dos profesionais enxeñeiros é o "Coñecemento das bases e fundamentos biolóxicos do ámbito vexetal na enxeñaría» entre os que se inclúe o coñecementos dos distintos procesos fisiolóxicos da planta. Esta competencia require que o enxeñeiro teña coñecementos 
básicos sobre as características da auga e o seu papel na nutrición e no transporte das plantas, xa que son procesos básicos para o funcionamento da planta. Estes coñecementos básicos trátanse nesta unidade.

\section{Duración e destinatarios}

Os contidos desta unidade didáctica van dirixidos a estudantes do Grao en «Enxeñaría Agrícola e Agroalimentaria» con coñecementos previos de Bioloxía. Esta unidade serán impartidos en doce horas: cinco horas de docencia teórica, seis horas de prácticas de laboratorio e unha hora de titoría.

\section{OBXECTIVOS}

Dentro da materia de Fisioloxía Vexetal, será necesario acadar uns obxectivos xerais:

- entender os procesos básicos do funcionamento vexetal centrándose no metabolismo do carbono como base do crecemento primario da planta e a súa regulación e integración espacial e temporal;

- usar os coñecementos adquiridos como base para o estudio doutras materias relacionadas;

- analizar criticamente a información que lles damos baixo distintos enfoques;

- aplicar o método científico, de forma que poda resolver problemas novos, manexar a grande cantidade de información a que hoxe teñen acceso e facer un análise en profundidade dos distintos fenómenos fisiolóxicos.

Os obxectivos que se pretenden alcanzar nesta unidade didáctica "Relacións hídricas, nutrición e transporte nas plantas» son:

- coñecer o proceso de osmose e os compoñentes do potencial hídrico;

- comprender o transporte nas plantas a través do xilema e do floema e o proceso de nutrición;

- analizar as interaccións das plantas cos microorganismos na rizosfera;

- desenvolver a capacidade de manexo das técnicas no laboratorio utilizando os coñecementos teóricos adquiridos. 
Figura 1. Relación dos obxectivos da unidade didáctica (UD) cos obxectivos da materia

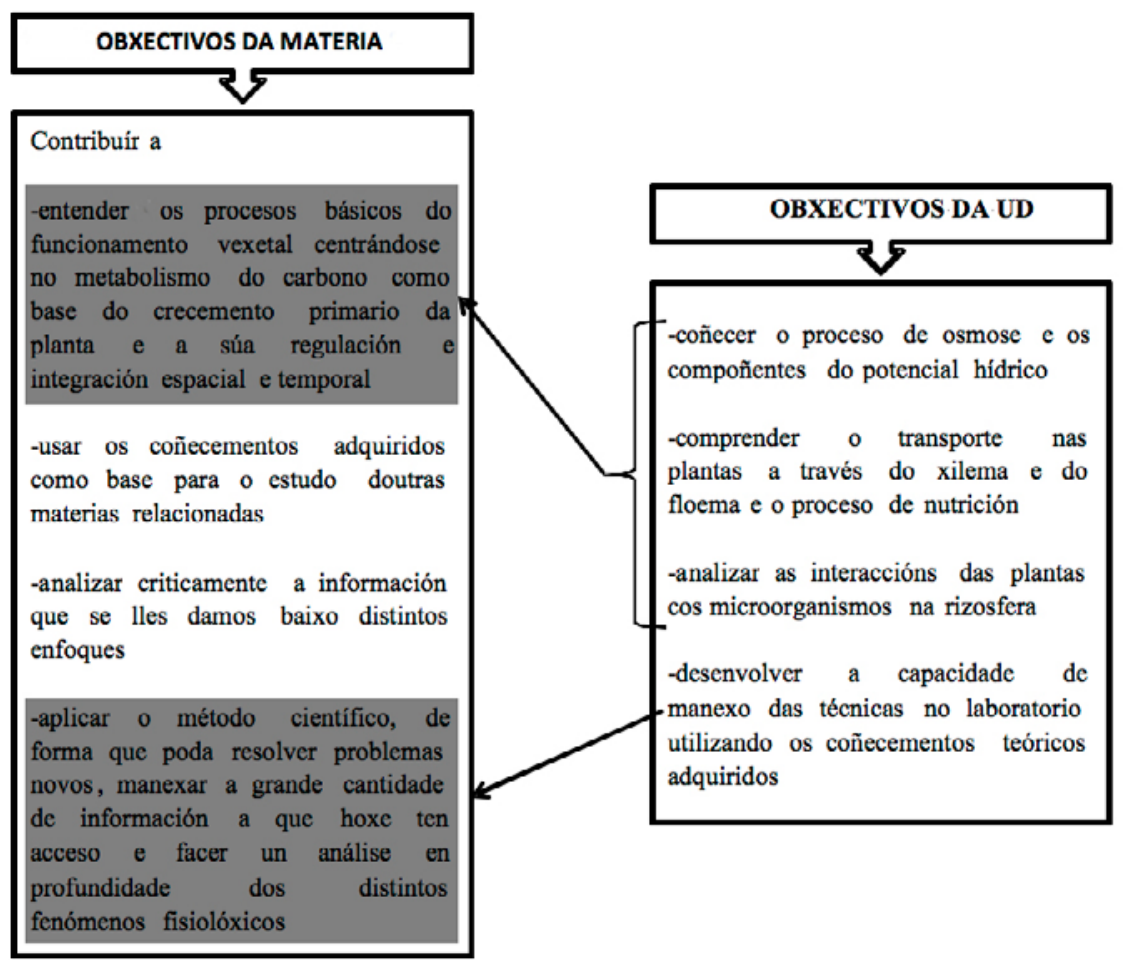

Fonte: Elaboración propia

\section{METODOLOXÍA}

Para o desenvolvemento dos contidos teóricos da unidade didáctica empregaranse cinco horas de clases expositivas de unha hora cada una que se desenvolverán en clases maxistrais na aula en grupo completo. Estas clases impartiránse co apoio da proxección de presentacions con diapositivas que sirvan de guía a exposición e o encerrado para explicar algúns conceptos ou procesos así como para resolver algunha dúbida. Os alumnos terán dispoñibles estas presentacións na USC virtual da materia que lles permitirá o seguimento das clases. Para fomentar a participación do alumnado formularánse preguntas relacionadas co tema actual e xa vistos anteriormente.

Os contidos prácticos desenvolveranse no laboratorio, en tres sesións de duas horas cada unha. Alí os alumnos traballaran en parellas e disporán dun protocolo de 
prácticas que poderán obter a través da USC virtual. É aconsellable que o alumno lera previamente o protocolo e que pregunte ao profesor todas as dúbidas que teña antes de empezar a práctica. $O$ alumno elaborará de cada sesión de práctica unha memoria onde aparecerá un resumo dos aspectos máis importantes da práctica e a resolución das cuestións formuladas no protocolo de prácticas.

A titoría desta unidade didáctica consistirá nunha sesión dunha hora onde os alumnos realizarán un pequeno control dos contidos da unidade didáctica, corrixirán o control dun compañeiro e posteriormente se corrixirá o control de forma colectiva.

\section{CONTIDOS}

Os contidos desta unidade didáctica dividénse nos siguientes apartardos:

\section{Propiedades físicas e químicas da auga}

A auga é o compoñente máis abundante nas plantas e constitue $85-95 \%$ do peso total da mesma, polo tanto é moi importante coñecer as súas propiedades. Nesta sección trátase de estudar as propiedades da auga tanto físicas como químicas e as funcions que as plantas adquiren grazas á presenza da auga. Estas propiedades exclusivas da auga fan que este medio sexa moi importante para elas. Na figura 2 podemos observar as propiedades da auga e as funcións que desempeñan na planta.

Figura 2. Propiedades físicas e químicas da auga e funcións adquiridas na planta

\begin{tabular}{|c||c|}
\hline PROPIEDADES FÍsICAS E QUÍMICAS & FUNCIÓNS ADQUIRIDAS \\
\hline Disposición espaciale polaridade & Disolución en auga doutras substancias \\
\hline Alta calor específica & Regulación térmica \\
\hline $\begin{array}{c}\text { Elevada calor latente de } \\
\text { vaporización }\end{array}$ & $\begin{array}{c}\text { Capilaridade e interacción con } \\
\text { superficies sólidas }\end{array}$ \\
\hline $\begin{array}{c}\text { Elevada adhesión, cohesióne } \\
\text { tensión superficial }\end{array}$ & \\
\hline
\end{tabular}

Fonte: Elaboración propia

Debido ás súas extraordinarias propiedades, é o solvente universal e existen moi poucas substancias que non sexan solubles en auga.

\section{Osmose e potencial hídrico}

\subsection{Osmose}

A osmose é unha forma especial de difusión onde se produce un movemento da auga a través dunha membrana semipermeable a favor dun gradiente de concentración de solutos. Polo tanto, a auga moverase dende unha solución hipotónica (con menor concentración de solutos) a unha hipertónica (con maior concentración de solutos). 


\subsection{Potencial hídrico}

Nesta sección explicarase o concepto de potencial hídrico e estudaranse os distintos compoñentes do potencial hídrico. O potencial hídrico é a capacidade das moléculas de auga para moverse nun sistema particular e polo tanto é unha medida da enerxía libre da auga no sistema.

Hai que ter en conta que o potencial hídrico mide a dispoñibilidade da auga libre dun sistema e polo tanto a auga moverase dende onde haxa máis auga libre (maior potencial hídrico) a menos auga libre (menor potencial hídrico). O potencial hídrico é a suma alxébrica de varios componentes:

$$
\Psi=\Psi_{p}+\Psi_{p}+\Psi_{m}+\Psi_{g}
$$

$\Psi_{\pi}=$ Potencial osmótico. Representa a diminución da capacidade de desprazamento da auga debido á presenza de solutos. A medida que a concentración de soluto aumenta, o $\Psi_{\text {p }}$ faise máis negativo. As moléculas de auga das disolucións moveránse dende lugares con pouca concentración de solutos a lugares con maior concentración de soluto. A auga pura ten un $\Psi_{\mathrm{p}}$ de 0 .

$\Psi p=$ potencial de presión. É nulo a presión atmosférica, positivo para presións por enriba da atmosférica, e negativo en condicións de tensión ou vacío.

$\Psi \mathrm{m}=$ potencial matricial. Representa o grao de retención da auga debido ás interaccións con matrices sólidas ou coloidais, pode valer cero se non hai interaccións, ou ser negativo.

$\Psi g=$ potencial gravitacional. Depende da altura, a nivel celular xeralmente omítese.

Na seguinte figura (Figura 3) aparecen os distintos compoñentes do potencial hídrico e a sua importancia non só na celula vexetal e a planta senón tamén no solo.

Figura 3. Compoñentes do potencial hídrico e a sua importancia

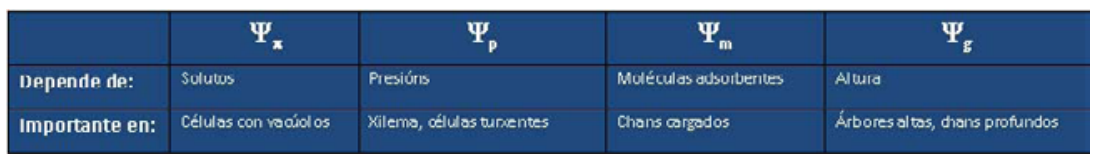

Fonte: Elaboración propia

Como xa vimos anteriormente, o potencial hídrico influirá no movemento da auga, producíndose un movemento da auga dende as zonas con maior potencial hídrico ás zonas con menor potencial. Este feito permitirá a entrada de auga na planta, o seu transporte polo xilema e a saída do vapor de auga polas follas (transpiracion).

\section{Absorción da auga e transporte polo xilema}

Nesta sección analízase o proceso de absorción da auga polas raíces e o seu transporte a través do xilema. A absorción da auga permite o seu desprazamento dende o solo ata a raíz, e é a primeira etapa do fluxo hídrico no sistema continuo solo-planta-atmosfera. 
A absorción da auga a través das raices acontece debido a que o potencial hídrico do solo é maior que o das raíces. Isto é debido a que no solo hai unha menor concentración de solutos que na raíz e polo tanto o potencial osmótico e hídrico do solo son maiores que os da raíz e isto produce a entrada a auga na raíz.

\subsection{Absorción da auga: ruta simplástica e apoplástica}

Neste apartado explicarase as rutas de absorción da auga e dos solutos. O sistema radical serve para suxeitar a planta ao solo e para encontrar a auga que a planta necesita. A auga entra especialmente polos pelos radicais que son longos e delgados e posúen unha elevada relación superficie/volume para introducirse a través dos pequenos poros do solo e absorber a auga. A auga e os solutos poden seguir dúas rutas: ruta simplástica e apoplástica (Figura 4).

\section{Figura 4. Ruta simplástica e apoplástica}

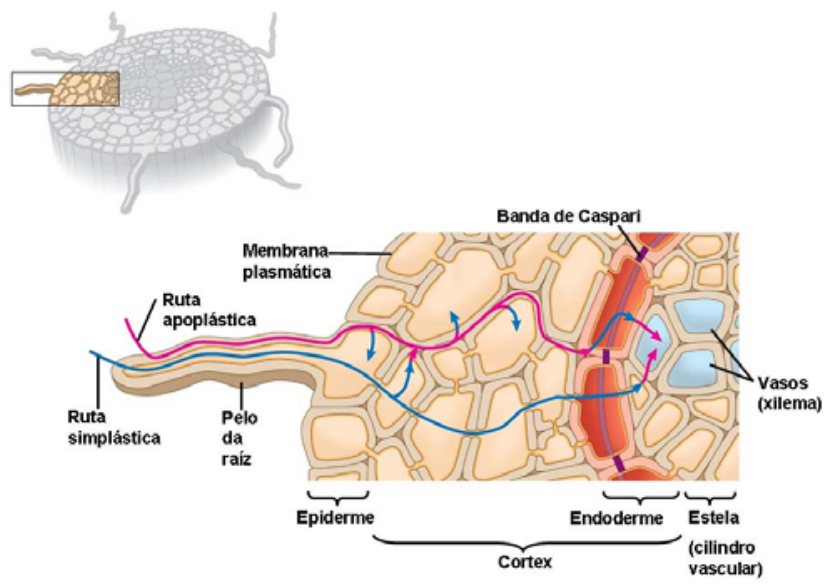

Fonte: Adaptado de Campbell e Reece, 2008

A ruta apoplástica está formada polas paredes celulares e os espazos intercelulares, mentres que a ruta simplástica son o conxunto de protoplastos das células (parte viva) interconectados mediante plasmodesmos. O camiño que seguen a auga e os solutos na planta pode ser apoplástico ou simplástico, ou unha combinación de ámbalas dúas.

A capa máis interna da corteza da raíz (endodermis) caracterízase porque as súas células dispoñense de forma compacta (sen deixar espazos intercelulares) e pola presenza da banda de Caspari (depósitos de suberina nas paredes celulares anticlinales e radiales da endoderme). Debido á presenza desta banda na endoderme, a ruta apoplástica presenta unha resistencia moi alta, e o fluxo de auga é forzado a atravesar pola ruta simplastica. 


\subsection{Transporte da auga polo xilema}

Neste apartado explícase o transporte da auga e dos solutos a través do xilema. Unha vez que a auga e os solutos atravesan a endoderme diríxense o xilema da raíz.

Os elementos condutores que compoñen o xilema son as traqueidas e as traqueas ou elementos dos vasos, que se dispoñen un detrás doutro formando os vasos. O ascenso da auga a través do xilema dende a raíces ata ás follas pódese explicar mediante a teoría de tensión-cohesión (Figura 5). Esta teoría está baseada en 3 forzas:

- Transpiración: É a perda de vapor de auga a través dos estomas das plantas. Hai un gradiente de $\Psi$ entre o solo, a planta e a atmosfera que permite o ascenso da auga dende o solo ata a atmosfera. A continúa transpiración xera unha tensión que arrastra a columna de auga permitindo que ascenda polo xilema.

- Tensión-cohesión: Os enlaces de hidróxeno entre as moléculas de auga (cohesión) e entre as moléculas de auga e as paredes do xilema (adhesión) crea unha forte columna de auga que non se rompe e ascenderá polo xilema.

- Presión radicular: Os solutos disoltos entran na raíz dende o solo grazas á osmose, xa que no solo a concentración de solutos e menor que na raíz e polo tanto o potencial hídrico é maior e entra a auga dende o solo ata a raíz creando unha presión radicular.

Figura 5. Forzas implicadas na teoría de tensión-cohesión

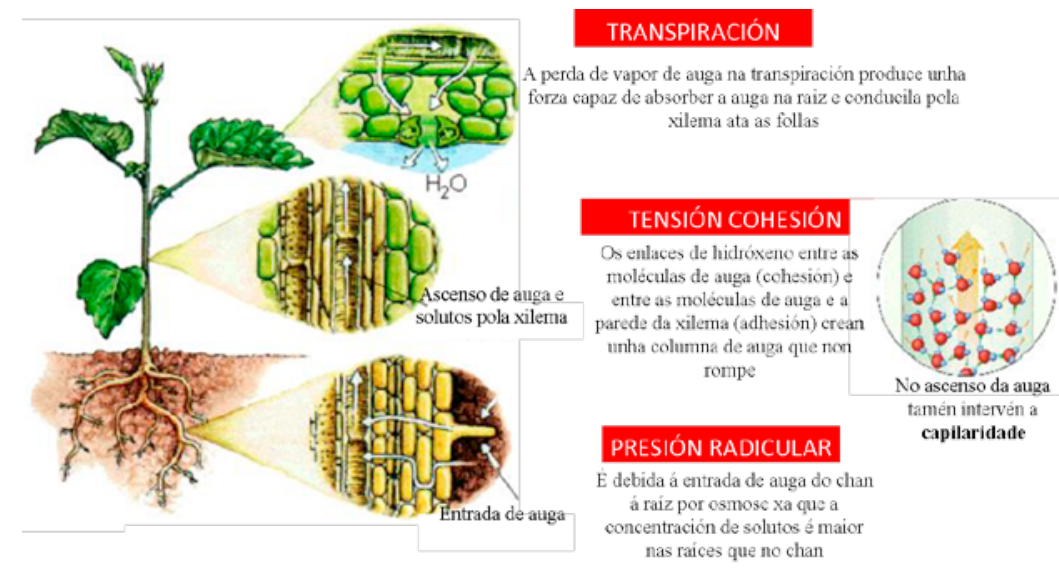

Fonte: http://docentes.educacion.navarra.es/metayosa/1bach/1nutriplanta2.html [citado 25 xuño 2015] 


\section{Transporte a través do floema: carga e descarga}

Nesta sección analízase o proceso de transporte a través do floema. Polo floema transpórtase o zume floemático formado por substancias orgánicas (azucres) producidas durante a fotosíntese (fotoasimilados).

As células condutoras do floema son os elementos cribosos que forman unhas series lonxitudinais chamadas tubos criboso. Os elementos criboso presentan poros, que forman áreas cribosas nas paredes laterais e placas cribosas nas paredes transversais. As placas cribosas posibilitan a comunicación entre elementos cribosos dun mesmo tubo criboso. As células acompañantes cumpren a función de carga e descarga dos elementos cribosoz trasportando lateralmente os fotoasimilados.

O movemento dos fotoasimilados segue un modelo de fonte a sumidoiro (Figura 6).

Figura 6. Transporte dos fotoasimilados entre a fonte e o sumidoiro

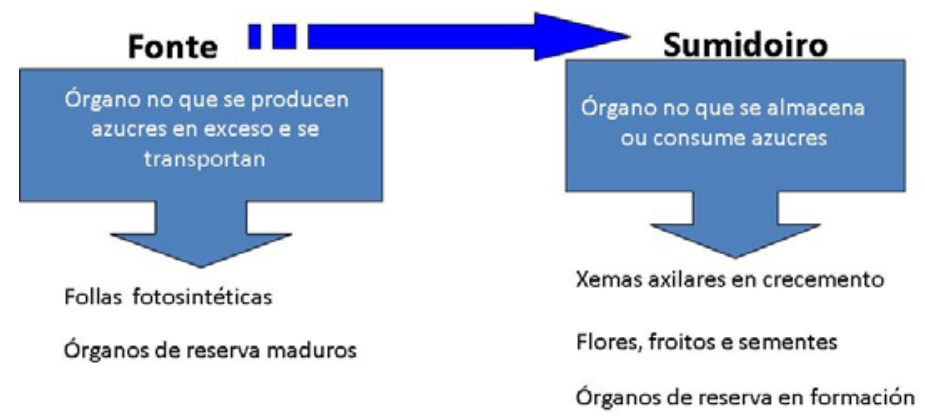

Fonte: Elaboración propia

As principais fontes de solutos asimilables son as follas fotosintetizantes, pero os tecidos de almacenamento poden servir tamén como importantes fontes. Todas as partes das plantas incapaces de satisfacer as súas propias necesidades nutricionais poden actuar como sumidoiros. Os tecidos de almacenamento actúan como sumidoiros cando están importando produtos asimilables e como fontes cando os exportan.

A hipótese de fluxo de presión (Figura 7) é o mecanismo xeralmente aceptado para explicar o transporte floemático. 


\section{Figura 7. Hipótese de fluxo de presión}

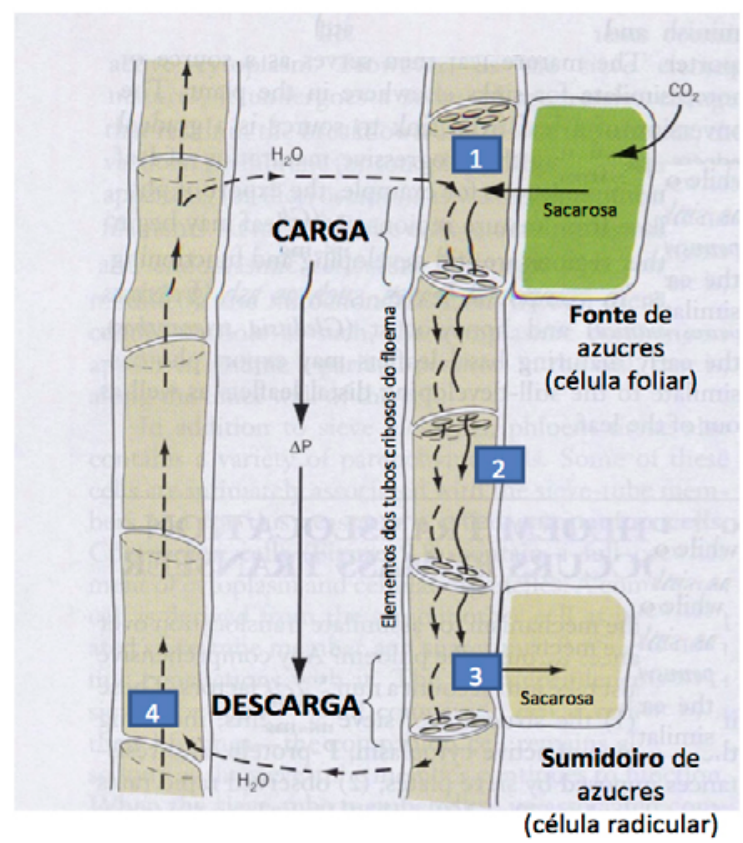

Fonte: Adaptado de Hopkins e Hüner 2009

Esta hipótese pódese resumir nos seguintes pasos:

- 1. Prodúcense azucres na fonte que son transportados aos elementos cribosos do floema (Carga) producíndose unha diminución do potencial hídrico. Esta diminución do potencial hídrico nos elementos cribosos do floema fai que penetra auga dende os elementos dos vasos do xilema.

- 2. Esta acumulación de solutos nos tubos cribosos próximos ao órgano fonte crea unha alta presión nesta zona e unha baixa presión no sumidoiro xerando un gradiente de presión que arrastra o zume floemático en dirección «fontesumidoiro".

3. Prodúcese a descarga no sumidoiro, diminuíndo os solutos nos elementos dos tubos cribosos do sumidoiro e polo tanto aumenta o potencial hídrico. Polo tanto a maior parte da auga difunde de novo ó xilema.

\section{O solo e a planta}

Nesta sección analízanse os nutrientes presentes no solo e os efectos que producen na planta a deficiencia destes. A maioría do peso seco da planta (90-95\%) está 
constituído por osíxeno, carbono e hidróxeno, principais compoñentes das substancias orgánicas que forman o corpo vexetal.

$O$ resto do peso seco está formado por nutrientes minerais esenciais para o correcto desenvolvemento da planta. Estes nutrientes son absorbidos polas raíces das plantas en forma de ións inorgánicos disoltos na auga. Distínguense dous tipos de nutrientes: os macronutrientes e os micronutrientes, segundo a cantidade do nutriente. Os macronutrientes (calcio, fósforo, magnesio, nitróxeno, potasio) acumúlanse na planta en cantidades considerables, mentres que os micronutrientes (boro, manganeso, ferro, cinc, cobre, molibdeno) están presentes en cantidades menores. Non obstante, algúns macronutrientes acumúlanse en menor cantidade que algúns micronutrientes.

\subsection{Deficiencia de nutrientes}

Neste apartado explicarase cómo a subministración inadecuada de un ou máis nutrientes esenciais provoca síntomas característicos de deficiencia. Centrarémonos en analizar os síntomas que provoca na planta, a deficiencia de nitróxeno, fósforo ou potasio entre outros (Figura 8).

Figura 8. Follas con deficiencia de nutrientes. (a) Folla de rosa con deficiencia en ferro. (b) Folla de tomate con deficiencia en fósforo. (c) Desenvolvemento da folla de feixón con deficiencia en cinc

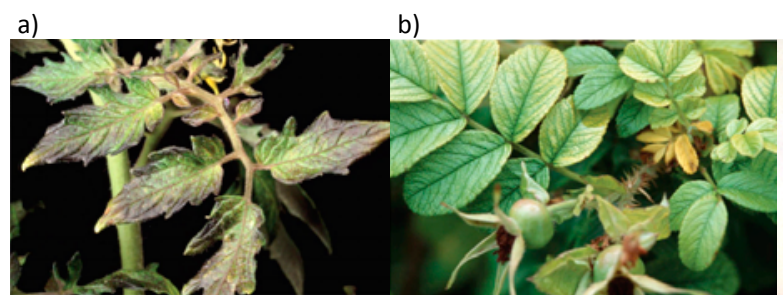

c)

Fonte: Adaptado de Mauseth, 2009

\subsection{Dispoñibilidade de nutrientes no solo}

Neste apartado abórdase o estudo dalgúns dos factores que afectan a dispoñibilidade dos nutrientes no solo. Entre os factores máis importantes está o pH do solo, onde un pH pouco ácido ou neutro aumenta a dispoñibilidade dos nutrientes. Outro factor esencial é a presenza no solo de partículas con carga negativa que poderán fixar ións moi importantes como o calcio impedindo a súa absorción pola raíz (Figura 9). 


\section{Figura 9. Distribución de catións no solo}

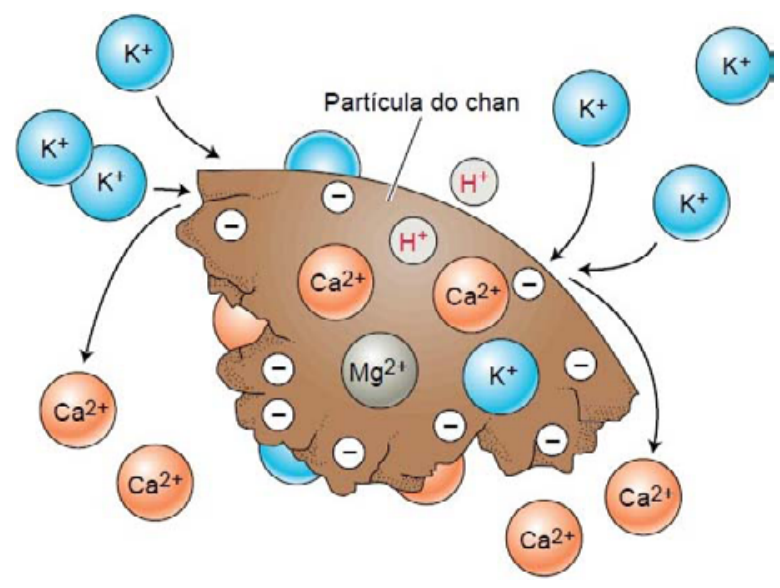

Fonte: Adaptado de Taiz, Zeiger, Møller, 2015

E por último a escaseza de osíxeno fai que predominen as formas menos solubles e polo tanto menos absorbibles polas raíces.

\subsection{Solos salinos e ácidos}

Neste apartado analizarase dous tipos de solos: os salinos e os ácidos e as características de ambos solos.

\subsubsection{Solos salinos}

Poden ter unha orixe antrópica ou natural. No primeiro caso pode ser producida polo excesivo uso de fertilizantes nas zonas agrícolas ou pola salificación derivada da contaminación ambiental. A salinidade tamén pode producirse nos solos de forma natural como nas zonas intermareais. En ambos os dous casos a salinidade causa nos solos dous fenómenos: toxidade iónica xa que os ións sodio e cloruro son tóxicos a altas concentracións e por outra parte produce estrés hídrico. $O$ estrés hídrico prodúcese porque a alta concentración de ións sodio no solo despraza os ións útiles (unidos ás partículas do solo cargadas negativamente) ás augas subterráneas.

Hai dous grupos de plantas segundo a súa resposta á elevada concentración de sal no solo: as plantas glicófitas ou non halófitas que non son capaces de resistir unha alta concentración de sal no solo e as plantas halófitas que son capaces de completar o seu ciclo vital no solo con alta concentración de sal (solos salinos). Estas últimas sintetizan na raíz sales e compostos osmóticos que almacenan nos vacúolos da raíz. Polo tanto diminúe na raíz o seu potencial osmótico e hídrico e polo tanto son 
capaces de tomar auga do solo. De non realizar esta estratexia as plantas en medios salinos perderían auga.

\subsubsection{Solos ácidos}

A chuvia e a descomposición da materia orgánica do solo son factores moi importante que contribúen á diminución do $\mathrm{pH}$ do solo. O aumento dos protóns no solo, fai que estes se enlacen fortemente ás arxilas (cargadas negativamente) desprazando catións importantes para a planta ás augas subterráneas. Para paliar a acidez destes solos pódese usar substancias de carácter básico como o cal.

\section{Absorción de nutrientes pola raíz}

Nesta sección estudarase o proceso de absorción de ións inorgánicos pola raíz. A auga entra nas células da raíz por un gradiente de $\Psi$, e os ións por transporte activo ou pasivo. $O$ transporte pasivo acontece cando o transporte é a favor do gradiente de concentración, non consume enerxía e pode requirir proteínas de transporte. 0 transporte activo acontece en contra de gradiente, consome enerxía e precisa de proteínas bombeadoras (Figura 10).

Figura 10. Transporte a curta distancia: Transporte activo e pasivo

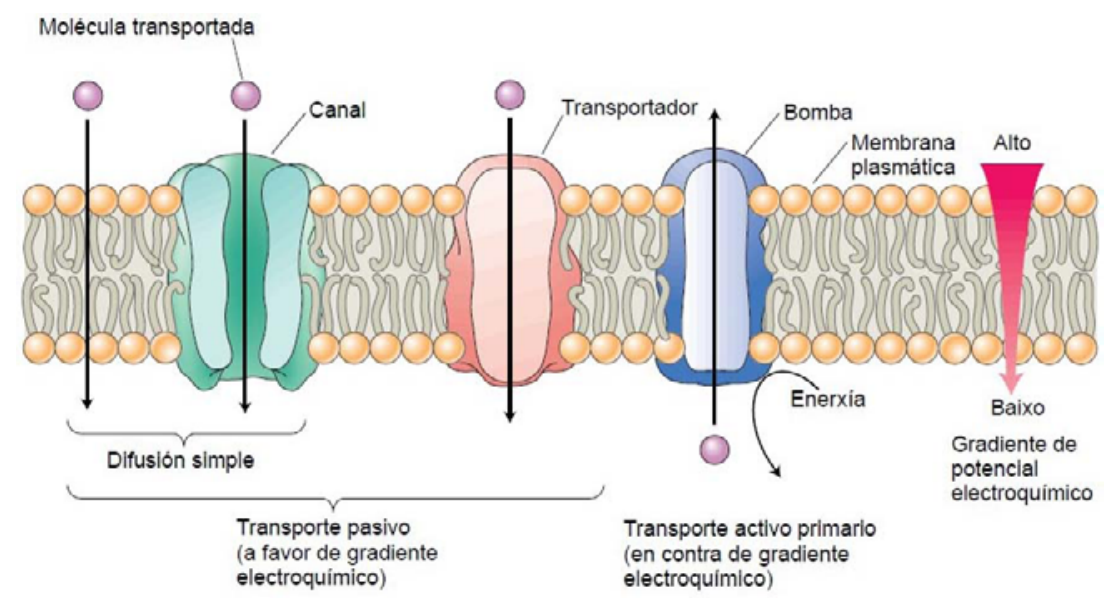

Fonte: Adaptado de Taiz, Zeiger, Møller, 2015

Na absorción de nutrientes pola raíz, hai dous procesos de transporte activo mediado por transportadores de membrana: na membrana das células epidérmicas permitindo a absorción dos ións dende o solo e na membrana das células do parénquima vascular que participa na secreción aos vasos do xilema. Por outro lado 
no transporte dende a epiderme ata a endoderme a ruta simplástica é a vía principal de transporte dos ións inorgánicos.

As ATPasas das células epidérmicas radicais excretan $\mathrm{H}^{+}$, os cales desprazan catións (ex. $\mathrm{K}^{+}$) do solo (intercambio catiónico) (Figura 11) que poden ser absorbidos pola raíz. Os pelos radiculares xeran os $\mathrm{H}^{+}$, de forma directa ou indirecta mediante a produción de $\mathrm{CO}_{2}$, orixinando na solución do solo unha reacción química que xera $\mathrm{H}^{+}$.

Figura 11. Intercambio catiónico entre a raíz e o solo

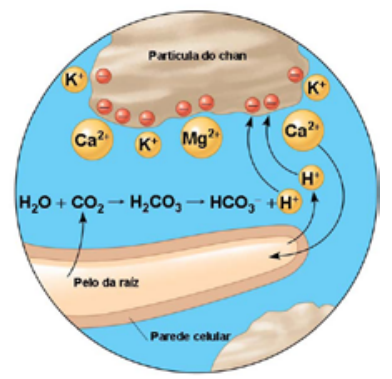

Fonte: Adaptado de Campbell e Reece, 2008

\subsection{Factores que afectan á absorción radical}

Neste apartado analízanse os factores que afectan á absorción radical. Distínguense dous tipos de factores exóxenos e endóxenos. Entre os exóxenos, o pH, a aireación ou a temperatura do solo inflúen na absorción dos nutrientes. Por outra parte, nos factores endóxenos cabe destacar a achega de fotoasimilados necesarios para a obtención de enerxía (respiración mitocondrial) para o transporte activo. Outro factor relevante é o crecemento da raíz que permitirá colonizar novas zonas do solo. E por último a presenza de micorrizas, asociacións simbióticas entre a raíz e os fungos que favorecen a absorción de auga e nutrientes (fósforo) por parte da planta.

\section{Interaccións con microorganismos na rizosfera}

Nesta sección trataranse as micorrizas e os nódulos, asociacións simbióticas que permiten a interacción dos microorganismos coa raíz, favorecen a absorción de fósforo e nitróxeno, respectivamente. 


\subsection{Nódulos}

Neste apartado estudarase as fases do ciclo do nitróxeno: fixación do nitróxeno, nitrificación, asimilación, amonificación e desnitrificación (Figura 12).

De todos os minerais, o nitróxeno é o que contribúe en maior medida ao crecemento das plantas e ao rendemento dos cultivos. As plantas requiren nitróxeno como compoñente das proteínas, ácidos nucleicos, clorofila e outras moléculas orgánicas importantes.

Hai dous tipos de bacterias do solo que permiten que a planta poida absorber o nitróxeno: as bacterias que fixan o nitróxeno atmosférico (bacterias fixadoras de nitróxeno), e as bacterias que descompoñen substancias orgánicas (bacterias amonificantes). Aínda que as plantas absorben parte dos ións amonio do solo, absorben fundamentalmente nitrato, que se produce a partir do amonio por acción das bacterias nitrificantes. As plantas reducen novamente o nitrato a amonio e logo incorporan o nitróxeno aos compostos orgánicos. O xilema transporta o nitróxeno dende as raíces ata os brotes en forma de nitrato, aminoácidos e diversos compostos orgánicos, segundo a especie.

Figura 12. Ciclo do nitróxeno

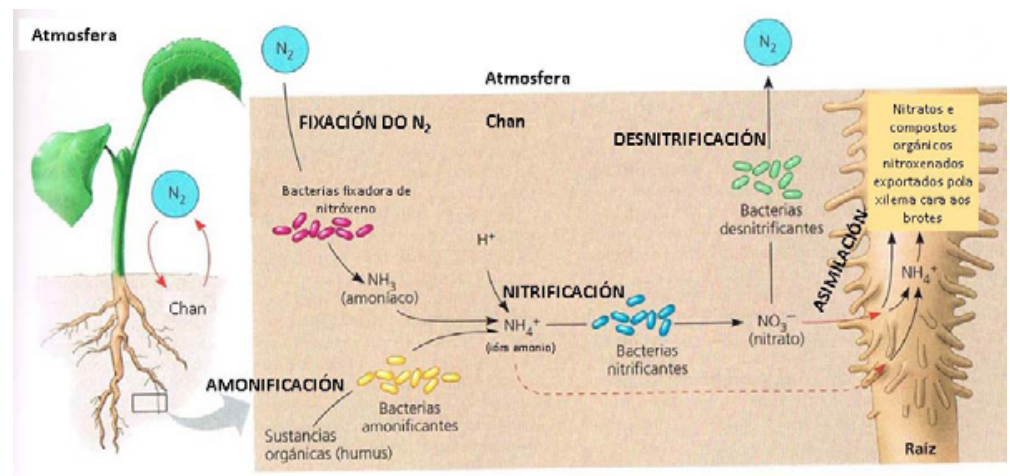

Fonte: Adaptado de Campbell e Reece, 2008

Así mesmo, en este apartado analizaranse os nódulos (Figura 13), asociacións simbióticas entre a raíz da planta e as bacterias fixadoras de nitróxeno que favorecen a absorción de nitróxeno. Dende o punto de vista agrícola, a simbiose máis importante e eficaz é entre bacterias fixadoras de nitróxeno e plantas da familia das leguminosas, como chícharo, alfalfa ou trevo. As raíces de leguminosas posúen nódulos compostos por células vexetais infectadas pola bacteria fixadora de nitróxeno Rhyzobium. Estas bacterias poden fixar o nitróxeno atmosférico e convertelo en amoníaco que a planta pode utilizar. 
Figura 13. Nódulos na raíz de soia Glycine max

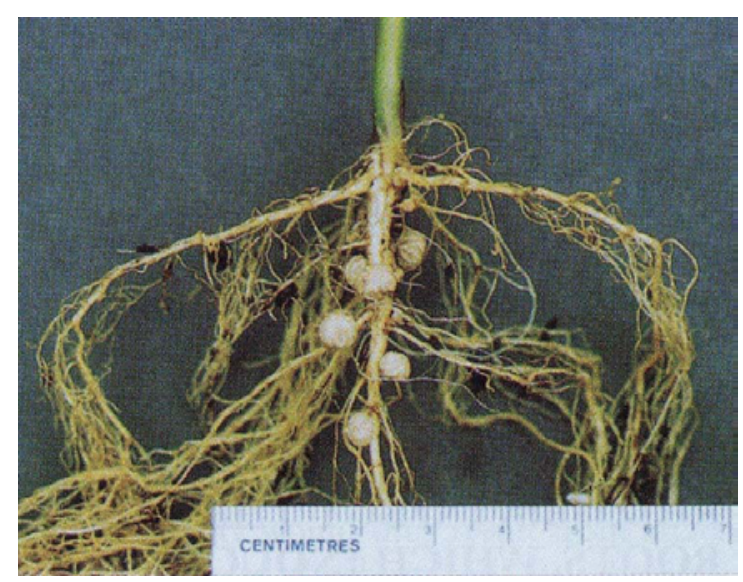

Fonte: Adaptado de Hopkins e Hüner, 2009

\subsection{Micorrizas}

Neste apartado explícanse as estruturas denominadas micorrizas, asociacións simbióticas entre fungos e as raíces das plantas, así como os tipos de micorrizas. Os fungos benefícianse coa subministración de azucre da planta hóspede e o fungo aumentan a superficie de absorción de auga e absorbe de forma selectiva fosfato e outros minerais do solo que son utilizados pola planta. Ademais, os fungos secretan antibióticos que poden axudar a protexer á planta de bacterias patóxenas e de fungos do solo. As micorrizas fórmanse na maioría das especies vexetais. As raíces modificadas que se forman pola simbiose de fungos e plantas teñen dúas formas principais: ecto e endomicorrizas (Figura 14). 
Figura 14. Micorrizas. (A) Ectomicorrizas. (B) Endomicorrizas

(a) Endomicorrizas

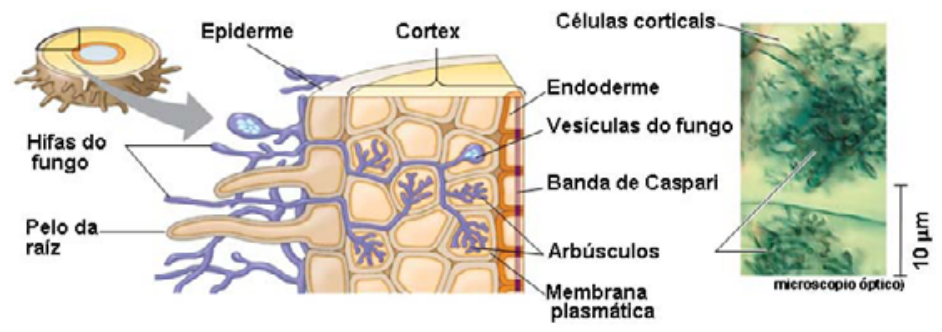

(b) Ectomicorrizas

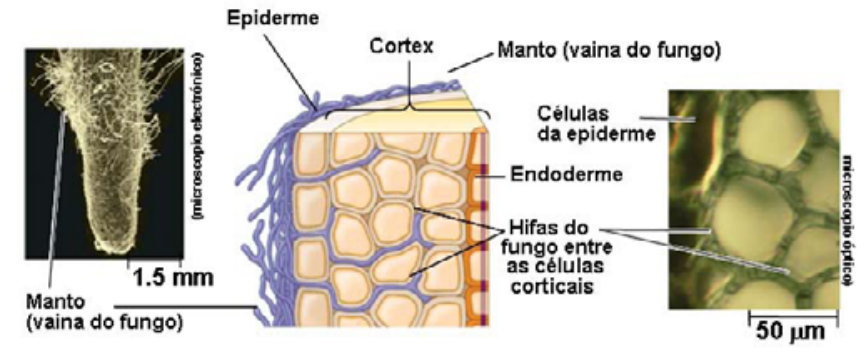

Fonte: Adaptado de Campbell e Reece, 2008

\subsection{Comparación entre micorrizas e nódulos}

Nesta sección, coa que remata a unidade didáctica, establécese unha comparación entre as dúas asociacións simbióticas vistas anteriormente (Figura 15).

Figura 15. Diferenzas e semellanzas entre micorrizas e nódulos

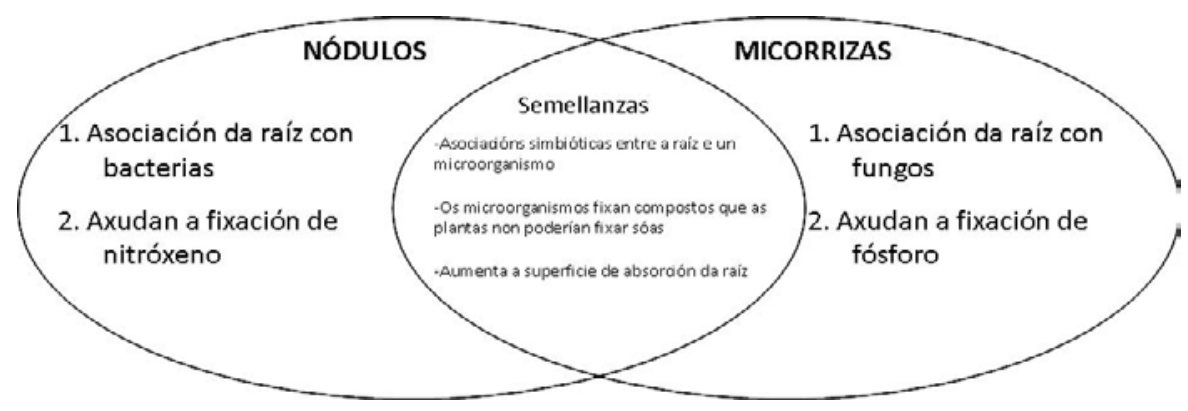

Fonte: Elaboración propia 


\section{ACTIVIDADES PROPOSTAS}

Desenvolveranse as seguintes actividades prácticas no laboratorio:

1. determinación do potencial hídrico polo método gravimétrico

2. reversión do transporte polo xilema

3. a transpiración: método gravimétrico e método do potómetro

4. efecto da concentración de cloruro sódico no crecemento da planta: estrés salino

Durante a primeira sesión realizaranse as actividades 1 e 2 . Na segunda sesión levarase a cabo a actividade 3 relacionada ca transpiración. Durante a primeira e segunda sesión prepararase o material vexetal necesario para a actividade 4 . Na sesión 3 prepararase a actividade 4 e os resultados desta actividade iranse observando ao longo do tempo.

A titoría desta unidade didáctica consistirá nunha sesión dunha hora: os primeiros 20 minutos os alumnos farán un breve control sobre a unidade, os 20 minutos seguintes os alumnos corrixirán o control dun compañeiro e os últimos 20 minutos corrixiranse as respostas de forma colectiva promovendo o debate entre eles. A corrección do control dun compañeiro estimula nos alumnos unha serie de competencias transversais: a capacidade analítica e crítica, a adaptación a novas situacións, así como a toma de decisións.

\section{AVALIACIÓN}

Os contidos teóricos avaliaranse durante a titoría mediante un control de dúas ou tres preguntas curtas nas que se valorará a adquisición dos coñecementos dos contidos teóricos desta unidade didáctica. Ademais valoraranse os contidos adquiridos nesta unidade didáctica mediante a realización dun exame parcial o que os alumnos poderán presentarse sempre que asistan regularmente ás clases teóricas e prácticas e participen activamente nelas, ademais dos exames oficiais aos que todos os alumnos poderán presentarse. Nestes exames valoraranse os coñecementos teóricos adquiridos de toda a materia.

En canto ás prácticas é importante sinalar que a asistencia s é obrigatoria. A falta de asistencia a algunhas das práctica pode ser compensada mediante un exame escrito coincidindo co exame teórico da materia. A avaliación das prácticas farase mediante a observación do alumno durante a práctica e a valoración da memoria de prácticas.

$\mathrm{Na}$ avaliación final terase en conta a nota obtida nos exames e no controis así como a actividade desenvolvida nas clases prácticas e a participación activa nas actividades, de acordo co seguinte cadro (Figura 16). 
Figura 16. Aspectos a avaliar e peso relativo de cada parte

\begin{tabular}{|c|c|c|c|}
\hline Aspecto & Criterios & Instrumento & $\begin{array}{c}\text { Porcentaxe da } \\
\text { nota final }\end{array}$ \\
\hline Participación & $\begin{array}{l}\text { Participación } \\
\text { activa nas } \\
\text { actividades }\end{array}$ & $\begin{array}{l}\text {.Observación } \\
\text { do profesor } \\
\text {.Pasar lista }\end{array}$ & $5 \%$ \\
\hline \multirow[t]{2}{*}{$\begin{array}{l}\text { Conceptos } \\
\text { teóricos }\end{array}$} & $\begin{array}{l}\text { Dominio dos } \\
\text { coñecementos } \\
\text { teóricos }\end{array}$ & $\begin{array}{l}\text {.Exame teórico } \\
\text {.Titorías }\end{array}$ & $10 \%$ \\
\hline & $\begin{array}{l}\text { Limpeza e orde no } \\
\text { traballo } \\
\text { Comprensión dos } \\
\text { procesos }\end{array}$ & $\begin{array}{l}\text { Observación } \\
\text { do profesor }\end{array}$ & $35 \%$ \\
\hline Prácticas & $\begin{array}{l}\text { Claridade e rigor } \\
\text { da memoria }\end{array}$ & $\begin{array}{l}\text { Corrección da } \\
\text { memoria }\end{array}$ & \\
\hline
\end{tabular}

Fonte: Elaboración propia

\section{BIBLIOGRAFÍA}

Azcón-Bieto Joaquín e Talón Manuel (2008): Fundamentos de Fisiología vegetal, Madrid: McGraw-Hill Interamericana.

Campbell Neil A e Reece Jane B (2008): Biology, Madrid: Editorial Médica Panamericana.

Epstein Emanuel e Bloom Arnold J (2005): Mineral nutrition of plants: principles and perspectives, Massachusetts: Sinauer Associates, Inc Publishers.

Hopkins William G e Hüner Norman PA (2009): Introduction to plant physiology, Nueva York: WilleY.

Mauseth James (2009): BotanY: An Introduction to Plant Biology, Massachusetts: Jones and Bartlett Publishers.

Taiz Lincoln, Zeiger Eduardo, Møller lan M e Murphy Angus (2015): Plant physiology, Massachusetts: Sinauer Associates, Inc Publishers.

\section{Recursos en internet}

La nutrición en los vegetales. http://docentes.educacion.navarra.es/ metayosa/1bach/1nutriplanta2.htm [citado 25 xuño 2015] 


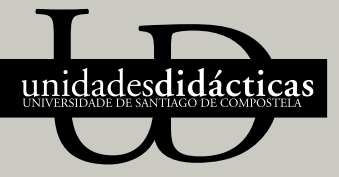

Unha colección orientada a editar materiais docentes de calidade e pensada para apoiar o traballo do profesorado e do alumnado de todas as materias e titulacións da universidade 